\title{
Microbiological Stability of A Pasteurized Prebiotic Beverage Composed by Cashew-Apple and Yacon During Refrigerate Storage
}

\author{
Maria de Fatima Borges (I), Ana Paula Dionísio (I), Nédio Jair \\ Wurlitzer (I), Bruna Santana Chagas (II), Maria Karolina de Araújo \\ Barroso (II), Ana Rafaella Alencar Braz (II), Adna Lucianne Girao \\ Modesto (I) \\ (I) Embrapa - Empresa Brasileira de Pesquisa Agropecuária (Rua Dra. Sara Mesquita, 2270, \\ CEP 60.511-110, Fortaleza, Ceará, Brasil), (II) UFC - Universidade Federal do Ceará (Caixa \\ Postal 12168, CEP 60.021-970, Fortaleza, Ceará, Brasil)
}

\section{Resumo}

New consumption trends have lead to a consumer's approach to healthier and more convenient foods and beverages. Food products claiming a functional properties towards promoting health are eagerly accepted by consumers and likely to result in a decrease in mortality and improving the quality of life of the population. An example is the cashew-apple, a fruit rich in antioxidant compounds, such as ascorbic acid, carotenoids and polyphenols, extensively reported in the prevention of diverse types of cancer. In this way, new functional beverages based on fruit juices and others foods, as the yacon - a tuberous root that has a high content of fructooligosaccharides with prebiotic properties - are becoming popular due to their health promoting attributes. Considering that the thermal processing should ensure microbiological stability of the products, the objective of this work was to evaluate the effect of heat treatment on the inactivation of spoilage and pathogenic microorganisms during the storage of a prebiotic beverage, composed by cashew-apple and yacon. The beverage was formulated, pasteurized $\left(90^{\circ} \mathrm{C}\right.$ for $60 \mathrm{~s}$.) and then stored under refrigeration at $4{ }^{\circ} \mathrm{C}\left( \pm 1.5^{\circ} \mathrm{C}\right)$. The analysis of filamentous fungi and yeasts, fecal coliforms, E. coli, and Salmonella spp. were performed

\footnotetext{
Referência:

Maria de Fatima Borges, Ana Paula Dionísio, Nédio Jair Wurlitzer, Bruna Santana Chagas, Maria Karolina de Araújo Barroso, Ana Rafaella Alencar Braz, Adna Lucianne Girao Modesto. Microbiological Stability of A Pasteurized Prebiotic Beverage Composed by Cashew-Apple and Yacon During Refrigerate Storage. In: Anais do 12 Congresso Latinoamericano de Microbiologia e Higiene de Alimentos - MICROAL 2014 [= Blucher Food Science Proceedings, num.1, vol.1]. São Paulo: Editora Blucher, 2014. DOI 10.5151/foodsci-microal-156
} 
according to the methodology described in the Manual of Bacteriological Analysis (FDA Bacteriological Analytical Manual online) at intervals of 45 days, for a period of 225 days. The population of filamentous fungi and yeasts ranged from ${ }^{3}$ UFC.mL ${ }^{-1}$. The presence of total coliforms, E. coli and Salmonella spp. not been found in the prebiotic beverage. These results indicate that the product showed microbiological stability during shelf life and is in according with sanitary standards for food set by the Ministry of Agriculture, Livestock and Food Supply and National Health Surveillance Agency. The thermal treatment adopted in the prebiotic beverage was effective in reducing spoilage microorganisms, eliminate pathogens and secured the microbiological stability of the product during 225 days of storage.

Palavras-Chave: prebiotic beverage, phenolic compounds, fructooligosaccharides, Smallanthus sonchifolius, microbiological safety Agência de Fomento: $\mathrm{CNPq}$ 